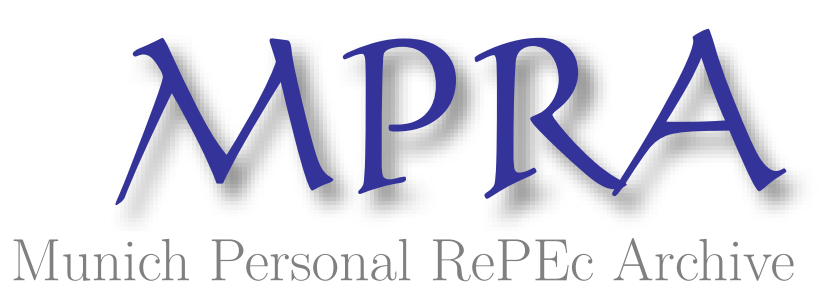

\title{
The Geography of Retail Inventory
}

Lai, Richard

Harvard Business School

21 March 2005

Online at https://mpra.ub.uni-muenchen.de/4755/

MPRA Paper No. 4755, posted 07 Sep 2007 UTC 


\title{
The Geography of Retail Inventory
}

\author{
Richard Lai \\ Harvard Business School \\ Morgan Hall T47A \\ Boston, MA 02163 \\ Tel: (617) 4956228 \\ Fax: (617) 4964397 \\ Email: rlai@hbs.edu
}

December 29, 2005

How different are retailers' inventory levels around the world? Specifically, are retailers' inventories constant across countries, converging, or at least co-integrating? These might be viewed as various forms of "global determinism." To see which of these forms hold, I use a novel dataset integrated from Dow Jones, Edgar, Bureau van Dijk (Europe), World'Vest Base, Multex, KIS (Korea Information Service), Teikoku of Japan, Huaxia of China, and COMPUSTAT. The dataset consists of 27,000 firm-year observations for 4,100 retailers in 23 countries, for the period 1983 through 2004 . I find evidence to reject all the three forms of global determinism. Instead, I report evidence consistent with an alternative hypothesis - "local contingency" - in which country effects can explain inventory differences around the world. I also show that this conclusion is robust in numerous ways.

\section{Keywords:}

Inventory, retailing, international comparison, global determinism, local contingency 


\section{The Geography of Retail Inventory}

How different are inventory levels in firms around the world? There are several reasons why this is an important question. First, it is important to determine just how well firms are doing in inventory management, given a spate of operational improvement programs - e.g., just-in-time. This is also the motivation for a recent set of papers that uses the U.S. as a setting - e.g., Chen, et al. (2005b), Gaur, et al. (2005), Netessine and Roumiantsev (2005), Rajagopalan and Malhotra (2001). ${ }^{1}$ Operational improvement programs are not limited to the U.S., or Japan. Indeed, for years, firms in countries like Singapore, Taiwan, and more recently, Malaysia, have "Look East" (i.e., toward Japanese management techniques) policies - often under government encouragement. Therefore, a study of firms around the world provides a more general understanding of how well such programs fare.

A second motivation speaks more directly to why it is important to study firms in countries other than the U.S. American firms are aggressively extending their supply chains internationally (e.g., Prasad and Babbar (2000) for a survey on research in international operations management) or investing overseas. Back in the U.S., many of them also face increasing foreign competition, whether through imports or foreign firms establishing themselves in domestic markets. It is vital to understand how non-U.S. firms whether supply chain partner, potential acquisition target, or competitor - are managing their inventory.

A third motivation concerns public policy. It is important to know whether country effects - such as infrastructure, institutions, demographics - matter to firm-level operational matters like inventories. For example, the World Bank is interested in whether such country effects influence the cost of doing business via the holding of inventories (see Guasch and Kogan (2004)).

In this paper, I choose to study retailers. Among many types of firms, retailers tend to hold large amounts of inventory. For example, the median U.S. retailer holds almost $20 \%$ of their cost of goods sold

\footnotetext{
${ }^{1}$ Other papers look at narrower sections of the economy. For example, Lieberman and Demeester (1999) study 52 Japanese automotive suppliers. Cachon and Olivares (2005) study inventory in the US automobile industry.
} 
as inventory (details later). U.S. retailers hold $\$ 468$ billion in inventories in November 2005, a shade more than the $\$ 467$ billion held by manufacturers (Commerce (2006)).

Conceptually, there are two broad hypotheses on what one would expect looking at inventory data around the world (see Khanna and Rivkin (2001)). The first hypothesis is "global determinism." In this view, technologies and constraints are similar enough across countries that one would not expect dramatically different inventory levels. There are plenty of anecdotal opinions consistent with this view. For example, Taiichi Ohno (1988) at Toyota says he thought of the famed kanban (看板) system after observing it in the U.S. Today, Zara in Spain models its fashion production and distribution system after Toyota's (Ferdows, et al. (2004)). Some modern statements of this view, usually in the literature on economic growth and cross-country comparison of technologies, are in Aghion (2004) and Islam (2003).

Pit against the "global determinism" view is a "local contingency" hypothesis. In this view, local conditions - infrastructure, institutions, etc. - create different equilibria for countries, so that inventory management could be persistently different around the world. This view is consistent with some theorists such as North (1990). There is some suggestive, although tangential, empirical support. For example, Bernard and Jones (1996) document that production technologies do not converge, even among OECD countries. Local contingency predicts that levels in inventory could be very different among countries.

In section 1, I articulate more nuanced hypotheses to be empirically tested, all using global determinism as the null. In "strong" global determinism, the hypothesis is that inventory levels are the same in all countries. In "semi-strong" global determinism, the hypothesis is that inventory levels might be different, but they are converging. In "weak" global determinism, the hypothesis is that inventory levels might not be converging, but they are still related in the long-term (i.e., co-integrated, in time-series definition). I call these three hypotheses using mnemonics: constancy, convergence, and co-integration. I bring to bear extant literature on these hypotheses, and embellish some of them. For example, I distinguish beta- and sigma-convergence in semi-strong global determinism, a distinction useful and borrowed from the economics of growth. 
In section 2, I describe some empirical antecedents that related to the above hypotheses. I find that the evidence for them is, at best, mixed.

In section 3, I describe how I assemble a dataset to document retailers' inventory levels and trends around the world, to see whether global determinism or local contingency prevails. The dataset includes more than 27,000 firm-year observations for 4,100 retailers in 23 countries, for the period 1983 through 2004. I assemble the dataset from a variety of sources, such as Osiris, COMPUSTAT Global Vantage, and a proprietary database of the World Bank. It has many features different from those used in earlier U.S.-based studies. First, it includes not just public but also private firms. Second, it includes detailed firm-level information on inventory, detailed operating financial information, and different accounting methods used (e.g., cost accounting method, inventory accounting method). Third, it has country-level data, including not only macroeconomics but also on characteristics that might influence supply contracting and inventory policies, such as openness to trade (e.g., customs and import duties as percent of tax revenue), rule of law (e.g., percent of managers surveyed who lack confidence in courts' upholding property rights), or infrastructure (e.g., total length of the road system in the country).

In section 4, I describe my empirical method. For robustness and to provide a sense of aggregation bias, I test the estimations at two levels of analysis: country (i.e., using the median-firm to represent each country) and firm (i.e., controlling for firm and industry heterogeneity). .I defer discussion of sensitivity tests, such as tests for sample selection bias, to a later section on robustness.

In section 5, I report evidence against all forms global determinism - constancy, convergence, or cointegration. However, there is some evidence of regional determinism. For example, in the cointegration test, I find that as many as $37 \%$ of the 192 country pairs have co-integrated levels at the $1 \%$ significant level (and as many as $74 \%$ at the $10 \%$ significant level). The interpretation is that while inventory levels are not co-integrated across all countries, they do seem to be co-integrated among subsets of countries.

In section 6, I report a number of robustness tests to rule out alternative interpretations. In particular, I run tests on sub-samples with homogenous accounting conventions and listing status to show that the 
results are not driven by systematic heterogeneity on these dimensions. I also run the Heckman correction procedure and report that the results are also not due to sample selection bias. To further bolster the claim that global determinism is rejected, I correlate country differences - after partialling out firm and industry heterogeneity - with country characteristics. In other words, I want to see if country differences are indeed driven by country effects. I use both least squares and differences-in-differences Tobit approaches. There is evidence that the differences in openness to trade, contracting environments, and to a lesser extent, physical infrastructure, are the most important explanations for differences among countries' inventory levels. Just as important (and perhaps surprisingly), some commonly thought explanations such as differences in economic development (e.g., Guasch and Kogan (2004)), inflation, or interest rates do not explain these differences.

In section 7, I conclude with some theoretical and practical implications. I also discuss questions not answered in this paper. For example, I focus on how different are inventory levels across countries, and provide preliminary evidence on "why," in the form of country characteristics that correlate with inventory differences. But I have not answered how much of the inventory variance could be explained by country differences, as opposed to say, firm or industry differences. For example, firms could have different inventory levels due to country differences, but inventory differences due to firm or industry differences could be still larger. I have also not delved deeper into the causes or provided a theory for why there is co-integration among many countries, why some country pairs are more co-integrated than others, or why some characteristics matter more than others in explaining inventory differences. And I have not made the connection to performance. Nevertheless, in my judgment, the question in this paperhow different are inventories across countries - is the first order of business. Given the size of the task in rigorously addressing just this question, I leave other issues to further studies.

This paper makes two contributions to the literature. First, I extend the type of analyses done for the U.S. to 22 other countries. The key stylized fact uncovered in this study is that (many) countries exhibit some weak global determinism. Among firms in the remaining countries, the differences in inventories seem to be best explained by institutional differences - contracting environment, infrastructure - rather 
than macroeconomic differences. A second order contribution is that set of staged hypotheses used to test what it means for two countries to have the "same" inventory levels. This framework of hypotheses could be used to test other areas of operational differences, such as firm differences in capacity investments or research \& development spending.

\section{HYPOTHESES}

Given the importance of understanding operational management in other countries, whether from the perspective of MNCs or indigenous firms, it is important that we can rely on some basic facts about operations management around the world. Specifically, how different are inventory policies in firms around the world, as observed in levels and trends? I focus on inventory because it is "commonly used to measure performance of inventory managers, compare inventory productivity across [firms], and assess performance improvements over time" (Gaur, et al. (2005), pg. 181).

One way to characterize how different are inventories is to borrow a framework from the study of multinational businesses. In reviewing the case of multinationals, Ghemawat (2003) remarks that on the one hand, there is evidence "the observed levels of cross-border integration... are significant and in many cases have recently reached highs without historical precedence...[on the other hand,] "cross-border integration are also very far from complete and, extrapolating from historical rates of increase (not to mention recent setbacks), are likely to remain that way for a long time.” (pg. 139)

Ghemawat's views characterize two competing answers - "global determinism" versus "local contingency." In the context of inventory management, forces for global determinism could include the cross-border integration of multinationals, as well as diffusion of management techniques such as those via cross-border mergers and acquisitions, cross-border competition, or training of managers. They could also include shocks that affect firms in all countries, such as global interest rates, freight prices that are subject to global oil prices, or global institutions like the World Trade Organization. All these affect firms' lead times, demand variability, service level requirements, and other factors that enter the inventory equation.

Forces for local contingency might include differences in markets, institutions, infrastructure, 
demographics, and other geographic factors that impinge on firms' inventory management. For example, Goonatilake (1990) argues that firms in developing countries are more likely to operate in less competitive environments and therefore have less incentive to manage inventory tightly. Chikan and Whybark (1990) suggest that indigenous and cultural factors in South Korea, China, Hungary, and Western Europe lead to different inventory practices in these places. They also estimate that in China, only 4.7 to $12 \%$ of production is market-driven. Yi and Gershon (1988) describe how Chinese stateowned enterprises, who obtain their supplies on request to the government, have incentives to over-state their requirements. Kornai (1979) argues that soft budget constraints can explain why shortages and excess inventory appear in such countries. The lack of an efficient credit market also forces firms toward corner solutions.

The theoretical challenge in formulating the ideas of global determinism and local contingency is to operationalize them in ways that could be falsifiable with empirical testing. There seems to be no one standard way to say whether global determinism or local contingency prevails. Thus, I propose that a useful way is to consider varying degrees along a spectrum. Specifically, using global determinism as a null hypothesis, I propose a set of hypotheses ranging from "strong" global determinism" to "weak."

"Strong" global determinism predicts constancy. That is, inventory levels are predicted to be equal for all countries in a cross-section. This is not as far-fetched as it may sound, especially if one tests equality of inventory after controlling for firm and industry heterogeneity. Further, the idea that we have arrived at or are near global convergence is prevalent in many disciplines, from the macroeconomics of growth prior to "new growth theory" (e.g., Fischer and Blanchard (1989)) to accounting standards and governance (Khanna, et al. (2006)).

"Semi-strong" global determinism predicts convergence. Inventory levels might be different, but tend to converge over time. As with the "strong" version, I shall test this hypothesis with and without conditional on firma and industry heterogeneity. This latter is reminiscent of unconditional versus conditional convergence in the literature on macroeconomic growth, in which the conditioning is on a country's endowments (see Islam (2003)). Borrowing again from that literature, I also make the 
distinction between beta and sigma convergence (e.g., Barro and Sala-I-Martin (1992)). The intuition of beta convergence is that, in a reduced form, firms with higher inventories reduce their inventories faster. However, beta convergence is necessary but insufficient for sigma convergence, where the intuition is that the dispersion of inventory among firms is reduced. Certainly, in macroeconomics, it is welldocumented that countries exhibit beta convergence, but not sigma convergence (see Friedman (1992)). This could be due to random shocks, or that some poor countries grow faster enough to overtake formerly rich ones (see Acemoglu, et al. (2002)). The analogy to the story in this paper is that firms too, could experience reversal in how they stack up in inventory management, so that we may observe only beta, but not sigma, convergence in the data.

"Weak" global determinism predicts co-integration. The idea here is that even if inventory levels are unequal and not converging, they at least move together. The formal notion for this is co-integration that is, the time series of the first difference in inventory levels for any two countries is integrated of order zero, I(0).

\section{EMPIRICAL ANTECEDENTS}

While I am not aware of any large-scale econometric study to uncover inventory differences around the world, a number of recent papers document the situation in the U.S. For example, Chen, et al. (2005b) and Rajagopalan and Malhotra (2001) look at inventory levels in the U.S. for manufacturers, and Gaur, et al. (2005) investigates likewise for retailers. There are also studies on individual countries other than the U.S., but these have focused on specific programs. For example, Lieberman and Demeester (1999) look at inventory reduction through just-in-time (JIT) programs at 52 Japanese automotive suppliers.

Cross-country studies tend to be specific to regions and programs. For example, Alles, et al. (2000) survey 116 plants worldwide, belonging to AT\&T, Boeing, Chrysler, Ford, HP, and Kodak. Their focus is on the effect of reduced inventories through JIT, rather than levels and trends. Other JIT studies across countries find differences - both perceptual as well as real. Baillie (1986) and Daniel and Reitsperger (1991) provide empirical evidence for Japan versus the U.S., Billesbach, et al. (1991) for the U.K. versus the U.S., and Matsuura, et al. (1995) for Japan versus Finland. Sum and Yang (1993) also show that 
implementation differences are large, for material resource planning (MRP) systems in the U.S. versus Singapore. Lieberman and Dhawan (2006) document the superior efficiency of Toyota over ten other auto manufacturers in Japan and the U.S., based on an analysis of WIP inventory. A few studies do look at inventory levels broadly, rather than tied to specific programs. For example, Chikan and Whybark (1990) survey firms South Korea, China, Western Europe and Hungary and conclude that more industrialized countries have lower inventory. Most of these papers are survey- or case-based, rather than use the large-scale econometric approach in this paper. Good coverage of these are in Prasad and Babbar (2000) and Prasad, et al. (2001).

Finally, our work is also related to research on inventory in economics. There, however, the emphasis is usually at the country or industry level, rather than our firm level. For example, West (1992) finds that inventory cycles in Japan and the U.S. are correlated. Also, there is a large literature on production efficiency across countries - e.g., Caves (1992) and Jorgenson (1988).

To sum up, while there are many bodies of research from different angles, none directly address the questions this paper seeks to answer.

\section{DATA}

There does not appear to be a sufficiently deep single source of data for the purpose of my analysis. I assemble my dataset from a number of sources. The main one is Osiris, an integrated dataset that is in turn assembled from Dow Jones, Edgar, Bureau van Dijk (Europe), World'Vest Base, Multex, KIS (Korea Information Service), Teikoku of Japan, and Huaxia of China. It covers 38,000 listed and major unlisted and delisted companies worldwide, 30,000 of which are non-US companies. A particularly important feature of the dataset is that Bureau van Dijk offers data that standardized across countries. Standardization is done on one of three formats: Anglo, Continental, and Hybrid. I choose Anglo, since the majority of the countries fit into this without standardization). I supplement this with COMPUSTAT's Global Vantage, both to check that the comprehensiveness of the Osiris integrated dataset (COMPUSTAT turns out to be largely a subset of Osiris) and to obtain important information on accounting conventions each firm adopts. From the combined dataset, I extract only those in retail 
(NAICS 2000 code 44 through 45). For a sense of the coverage of the dataset, COMPUSTAT claims that it covers "over $90 \%$ of the world's market capitalization, including coverage of over $96 \%$ of European market capitalization and $88 \%$ of Asian market capitalization." I set aside observations that do not have inventory information, and countries that have fewer than 100 observations. These observations are used later to test and correct for potential sample selection bias.

In Table 1, I summarize the resulting dataset, which includes more than 27,000 firm-year observations for 4,100 retailers in 23 countries, for the period 1983 through 2004 . Unsurprisingly, panel (a) shows that most of the inventory for retailers is in the form finished goods: the median firm has finished goods inventory (scaled by COGS, cost of goods sold) at 0.13 , while raw materials and work in progress inventories are negligible. The median firm has respectable financial performance, as reflected in its Tobin's $q$ ratio being above 1 . Also, minority interests are only $4 \%$, consistent with evidence that most countries have firms owned by large block holders (see La Porta, et al. (1999)).

Panel (b) shows the distribution by country. A notable feature of this distribution is that it spans a range of countries - big (e.g., US) and small (e.g., Singapore), rich (e.g., Sweden) and poor (e.g., China). A concern about big countries is that "country effects" are harder to pin down. Does China's average infrastructure affect Yimin Department Stores in Shanghai as much as it does the Tianlong Group, which is in Taiyuan city in Shanxi province, one of the poorer ones in northern China? In a way, this is addressed by the dataset, which picks up more big firms situated in larger cities. While Shanghai's GDP per capita is US\$ 5,620, Taiyuan's is a respectable $\$ 1,550$ (even though Shanxi's average GDP per capita is \$900; all 2003 figures) (China Statistical Bureau, (2005)). Taiyuan, being a prefecture capital, also receives disproportionate investments in national funds for infrastructure. Of the 10 major national expressways built after 1978, Taiyuan is on two (Shijiazhuang-Taiyuan, Taiyuan-Jiuguan), just like Shanghai (Shanghai-Nanjing, Beijing-Shanghai) (Mao (1996)). A second way to address this "big country" issue is to simply re-estimate the models using only observations from small countries. I undertake the latter as a robustness test.

Panel (c) shows the listing status, an important component since many firms in emerging markets are 
private. For robustness, I shall later run estimations using sub-samples with homogenous status.

A key concern with cross-country comparisons is whether such comparisons are meaningful, given differing accounting conventions. I address this in two ways. First, by following the literature in dividing inventory by cost of goods sold (e.g., Chen, et al. (2005b), Gaur, et al. (2005)), I can remove some variation that affects numerator and denominator in the same way. This is the approach I take in my baseline analyses. Second, in robustness checks, I marshal detailed information about various conventions our firms take and conduct analyses for sub-samples in which firm-years have the same conventions. In panels (d) and (e), I report the accounting conventions employed. These are used to construct the sub-samples.

Panel (f) shows country characteristics from country-year observations in a dataset that is later joined with the firm-year dataset for analysis. This country-year information is from the World Bank Indicators, who in turn obtained the information from national statistical agencies around the world. Consistency is ensured to a reasonable extent. For example, all agencies compile data according to at least the 1968 SNA (System of National Accounts), even as more and more are adopting the 1993 SNA. Furthermore, "data are shown for economies as they were constituted in 2003, and historical data are revised to reflect current political arrangements."

\section{METHOD}

For each of the hypotheses on constancy, convergence, and co-integration, I test at the country level (e.g., compare if inventories of the median-firms are equal) and at the firm level (e.g., test if country effects in a regression of firms' inventories on firms' countries are significant). The purpose of the country level test is to check against results in the (mostly economics) literature, and to see if there is aggregation bias, compared with the firm level tests. My claims are based on the firm level tests, since it is at that level that I can control for firm and industry heterogeneity.

I first test "strong" global determinism (constancy). At the country level, I use a Kruskal-Wallis test to check if inventories (scaled by COGS) among the countries' median firms are equal. For robustness, I calculate the medians using a variety of time periods, including in year cross-sections and over the entire 
period. At the firm level, I control for firm and industry heterogeneity:

$$
\begin{gathered}
\text { LOGINVENTORY }_{c i f t}=\text { COUNTRY }_{c}+\text { YEAR }_{t}+\text { INDUSTRY }_{i}+\text { GROSSMARGIN }_{c i f t}+ \\
\text { CAPITALINTENSITY } \\
\text { cift }
\end{gathered}
$$

where INVENTORY $Y_{c f t}$ is the inventory for firm $f$ in country $c$ in year $t$, scaled by contemporaneous cost of goods sold, COUNTRY $Y_{c}$ and $Y E A R_{t}$ the country and year effects, GROSSMARGIN cift $_{\text {is }}$ gross profit divided by sales, CAPITALINTENSITY $Y_{\text {cift }}$ is total inventory divided by the sum of total inventory and property, plant, and equipment, and $S A L E S G R O W T H_{c i f t}$ is the year-on-year sales growth, and $\varepsilon_{f t}$ is assumed to be white noise. I use these last three as firm controls given the evidence by Gaur, et al. (2005), who report that these account for over $97 \%$ of firm variation ${ }^{2}$. Notice that I cannot use firm fixed effects here, since my variable of interest is country, which is a time-invariant firm characteristic.

I test constancy using an $F$-statistic for equality of all country effects. All estimation for this as well as subsequent models (unless otherwise stated) is done with robust Huber-White standard errors, and clustered around industry to minimize serial correlation.

I next test semi-strong global determinism (convergence). At the country level, beta convergence holds if MEDIANINVENTOR $Y_{c t}$ is signed negative in the reduced form model below:

$$
\triangle \text { MEDIANINVENTOR } Y_{c t}=\text { MEDIANINVENTOR } Y_{c t}+\operatorname{COUNTR}_{c}+\varepsilon_{c t}
$$

where MEDIANINVENTOR $Y_{c t}$ is the median-firm's inventory (scaled by COGS) for country $c$ in year $t, \Delta$ the difference operator, $\operatorname{COUNTR} Y_{c}$ are country fixed effects, and $\varepsilon_{c t}$ is assumed to be white. Sigma convergence holds if $S D\left(M E D I A N I N V E N T O R Y_{t}\right)$ is smaller than one in the ARIMA(1) specification:

\footnotetext{
${ }^{2}$ Two qualifiers need to be made. First, they also include a fourth variable, sales surprise. This is not available
} for most countries. However, it is hard to imagine that these are correlated with country effects, so there does not appear to be an unambiguous story to suspect systematic omitted variable bias. Second, their evidence is only for U.S. retail industries. Again, one has to argue that there are specific omitted variables that correlate with country effects, my variables of interest. Importantly, I replicate Gaur, et al. (2005) with my dataset, regressing inventory on firm and year fixed effects with the three variables, and obtain a comfortable $87.5 \%$ adjusted $R$-squared. 
where SD is the standard deviation across countries. The corresponding tests at the firm level are similar, replacing MEDIANINVENTOR $Y_{c t}$ with country effects from equation (1).

Lastly, I test weak global determinism (co-integration). At each of the country and firm levels, I test if country trends are the same, and then if inventory levels are co-integrated. At the country level, the trend test involves examining the interaction of $C O U N T R Y_{c}$ (country effects) on $Y E A R_{c t}$ (trend):

$$
\text { MEDIANINVENTOR } Y_{c t}=\operatorname{COUNTR}_{c}+\operatorname{COUNTR}_{c} \times Y E A R_{c t}+Y E A R_{c t}+\varepsilon_{c t} .
$$

In the co-integration test, I first find the co-integration factor $\beta$. for each pair of countries 1 and 2:

$$
C_{l_{-}} Y E A R_{t}=\mu+\theta . Y E A R_{t}+\beta . C_{2_{-}} Y E A R_{t}+\eta_{t},
$$

where $\mathrm{C}_{-} Y E A R_{t}$ and $C_{2} Y E A R_{t}$ are median-firm inventory levels of the countries in year $t$. Then, I run augmented Dickey-Fuller tests are on the $192 \eta_{t}$ to see if they are $\mathrm{I}(0)$. The null is rejected if it is not the case that all 192 Dickey-Fuller statistics exceed their critical values.

\section{BASELINE RESULTS}

I describe the results in the order of the hypotheses. Figure 1 compares the inventory (scaled by COGS) of each country's median firm in the year 2004. Data for other years and the entire period are similar and are unreported. The key message is that the inventories do not seem to be constant across countries. Greece's level $(0.36)$ is more than seven times that of Korea's (0.06). Also, this range is much larger than the world median of 0.23 .

In Table 2, I report statistics for more formal between-country comparisons of medians. Panel (a) shows country level tests. In the top-most row, the median-firm inventory is calculated from all years combined. In the second row, I calculate country medians in the year 2004 cross-section. The test statistics easily defeat the null that medians are equal among countries, at the $0.1 \%$ significance level. Cross-sections for other years produce the same qualitatively results and are not reported. Panel (b) reports results for firm level tests. Many of the coefficients in the table are statistically not different from zero. However, an $F$-test that all the coefficients are equal (e.g., to zero, or any other value) is rejected at the $1 \%$ level. I interpret these as evidence to reject constancy of inventories across countries. 
In Table 3, I test of the convergence hypothesis. In panel (a), the coefficient for MEDIANINVENTOR $Y_{c t}$ is positively signed, suggesting that country medians are diverging. The test for sigma convergence is not statistically significant. Panel (b), which reports firm level results, gives qualitatively the same findings. Taken together, I interpret these as evidence rejecting convergence.

In Table 4, I report the co-integration results. In panels (a) and (b), I show tests at the country level. Panel (a) tests whether country trends are the same. Although most countries have statistically insignificant trends ${ }^{3}$, a joint test that all trends are equal is rejected at the $1 \%$ level. Panel (b), I report the portion of country pairs that exhibit co-integration in their inventory levels. Although a good portion$29.7 \%$ of the cells, at the $1 \%$ significance level - are co-integrated, this is clearly not global determinism in which all countries are co-integrated. In the next section on robustness analysis, I check if a looser regional determinism claim could make sense. In panels (c) and (d), I repeat the same using firm level analyses. Panel (c) shows that most country trends, corrected for firm and industry heterogeneity, are statistically indistinguishable from zero. But again, a joint test that the trends are equal is rejected at $1 \%$. Panel (d) likewise shows that only $31.2 \%$ of the cells are co-integrated. Taken together, I interpret all these as evidence that even weak global determinism can be rejected.

\section{ROBUSTNESS ANALYSES AND DISCUSSION}

Some types of robustness checks are already reported in the previous section. For example, I calculate medians using different time periods, and estimate models at both the country and firm levels to see if there is aggregation bias (there does not seem to be any). In this section, I report results of a more complete check for robustness, in several ways. First, I check if the sample is not representative of smaller sub-samples. In Table 5, panel (b), I report an example, in the test of strong global determinism at the country level (i.e., compared with Table 2, panel (a)). Specifically, I run the median-equality tests

${ }^{3}$ The statistically insignificant U.S. trend obtained here is consistent with that in Chen, et al. (2005a). In three specifications shown in their Table 2, two returns statistically insignificant trends (indeed, one is signed positively and the other negatively) and the third is significant and negatively signed. 
on sub-samples of just listed and just non-listed (delisted or unlisted) firms. As the panel reports, the null that country medians are the same is rejected for both sub-samples. The other sub-samples I use include those by cost accounting and inventory accounting methods. All these are used for the suit of tests presented earlier. The results are qualitatively unchanged, so I do not report them here. ${ }^{4}$

If the previous robustness test is to check if the conclusions might not apply to sub-samples, the second test is to check if the baseline sample is biased. Heckman (1979) proposes a correction procedure that is now standard in the literature. It involves a first-stage probit modeling of the selection of observations into the sample, followed by a second-stage correction of the structural equation, conditional on selection. The selection model I use is:

$$
S E L E C T E D_{f t}=Y_{E A R}+\operatorname{COMPUSTAT}_{f t}+\operatorname{ASSETS}_{f t}+\varepsilon_{f t},
$$

where COMPUSTAT $T_{f t}$ is an indicator variable for whether the observation comes from COMPUSTAT, and $\operatorname{ASSETS}_{f t}$ is the total assets of firm $f$ in year $t$. The intuition for this is that my baseline sample might contain observations that are systematically skewed by year, whether they are in COMPUSTAT (as opposed to Osiris), or size (with assets as a proxy). The addition of other regressors diminishes the strength of specification, as indicated by lower adjusted $R$-squared. In Table 5, panel (a), I show an example of the correction for strong global determinism at the firm level test (i.e., to be compared with the baseline in Table 2, panel (b)). I report only the comparison for this test because it shows the biggest potential for possible sample bias, as shown in the inverse Mills ratio. Even here, the ratio of 0.094 is not statistically significant; the standard error is 0.052 . Further, the earlier findings - that the coefficients are collectively and mostly individually indistinguishable from zero - stand up to the correction.

The third kind of robustness test is to check alternative interpretations of the claims. One concern is that the meaning of "geography" to firms in large countries could be vague. I re-estimate the results using a sub-sample of small countries, using several thresholds, including one with countries with less than the median area and another with just the smallest 5 countries (Singapore, Hong Kong, Netherlands,

\footnotetext{
${ }^{4}$ All unreported results are available from the author.
} 
Denmark, Ireland). The former is reported in panel (c), although all sub-samples produce the same qualitative result. The test replicated in panel (c) is the convergence test at the country level. As before, it appears that there is beta divergence, and there is no evidence of sigma convergence.

Since the claim is to reject global determinism, another robustness check is to check for local contingency (rejecting global determinism does not mean accepting local contingency). To do this, I see if inventory differences indeed correlate with country differences. I use both least squares and differences-in-differences Tobit approaches. The least squares approach assumes that inventory has an affine relationship with country characteristics. It is reported in Table 6, panel (a), where I show results of a specification using firm fixed effects and another using OLS. The advantage of using firm fixed effects is that model removes all time-invariant firm, industry, and country effects. Since it removes even country fixed effects, it has low power in discerning a correlation between inventory and country characteristics. Unfortunately, this is exactly what happens as shown in model (1). Model (2) uses:

$$
\begin{aligned}
& \text { LOGINVENTORY }_{\text {cift }}=\text { YEAR }_{t}+\text { INDUSTRY }_{i}+ \\
& \text { GROSSMARGIN }_{\text {cift }}+\text { CAPITALINTENSITY }_{\text {cift }}+\text { SALESGROWTH }_{\text {cift }}+ \\
& \text { GDPGROWTH }_{\text {cift }}+\text { LOGINFLATION }_{\text {cift }}+\text { LOGINTEREST }_{\text {cift }}+\text { LOGGDPCAPITA }_{\text {cift }}+ \\
& \text { LOGTRADE } / G D P_{\text {cift }}+\text { LOGPHONE }_{\text {cift }}+\text { LOGAIR }_{\text {cift }}+\varepsilon_{\text {cift }} .
\end{aligned}
$$

As before, I control for year and industry effects. I also control for firm effects as before, using gross margin, capital intensity, and sales growth. The coefficients are signed as what I expect. For example, looking at model (2) for aggregate inventory, the variables that lower inventory are inflation, and (very weakly) GDP per capita and physical infrastructure (LOGAIR). The result for inflation is consistent with Chen, et al. (2005b) and the result for GDP per capita consistent with Guasch and Kogan (2004), although the latter's analyses are at the industry level. Importantly, the country characteristics are collectively significant. The $F$-statistic is 11.74 , with a $p$-value close to zero. However, the economic significance is not high. The coefficients can be interpreted as elasticities. For example, a $1 \%$ improvement in physical infrastructure $(L O G A I R)$ is correlated with only a $0.06 \%$ reduction in inventory. Finally, the country characteristics produce only a small incremental adjusted $R$-squared of $5.8 \%$ over a model without the 
characteristics. Although the correlations are not meant to imply causality, I nevertheless estimate model (2) with up to 3 lags of the dependant variable, and instrument the regressors with the full set of country characteristics in Table 1, panel (f). The results are qualitatively the same, so I do not report them here.

One possible criticism of the above estimation is that it has an implicit prior about the optimality of inventory levels. Since inventory is a noisy measure of operational performance. It could be the result of incompetent operations, but it could also be the by-product of a high availability strategy (see Lai (2005)). To answer the question of what country characteristics correlate with differences in inventory levels, I next use a differences-in-difference technique. This technique also has the "potential to circumvent many of the endogeneity problems that typically arise when making comparisons between heterogeneous individuals" (Bertrand, et al. (2004), pg. 250). The dependant variable is the difference between pairs of countries $c 1$ and $c 2$ in year $t$, analogous to a metric used in Khanna and Rivkin (2001):

$$
\triangle \operatorname{COUNTR} Y_{c 1, c 2, t}=\log \left(\max \left(\operatorname{COUNTR} Y_{c 1, t}, \operatorname{COUNTR} Y_{c 2, t}\right) / \min \left(\operatorname{COUNTR} Y_{c l, t}, \operatorname{COUNTR} Y_{c 2, t}\right)\right)
$$

The independent variables include $\mathbf{\Delta} \mathbf{X}_{\mathbf{c l}, \mathbf{c} 2, \mathbf{t}}$, the matrix of differences in country characteristics. For example, the difference for GDPGROWTH is:

(9) $\triangle G D P G R O W T H_{c l, c 2, t}=\log \left(\max \left(G D P G R O W T H_{c l, t}, G D P G R O W T H_{c 2, t}\right) / \min \left(G_{D P G R O W T H}{ }_{c l, t}\right.\right.$, GDPGROWTH $\left.\left.H_{c 2, t}\right)\right)$ for countries $c 1$ and $c 2$ in year $t$. Other independent variables include $\mathbf{\Theta} \mathbf{X}_{\mathbf{c} \mathbf{1}, \mathbf{c} \mathbf{2}, \mathbf{t}}$, the average levels $-e . g$.:

$\Theta G D P G R O W T H_{c l, c 2, t}=\left(G D P G R O W T H_{c l, t}+G D P G R O W T H_{c 2, t}\right) / 2$.

The model is therefore:

$$
\Delta \operatorname{COUNTR} Y_{c 1, c 2, t}=\Delta \mathbf{X}_{\mathbf{c} 1, \mathbf{c} 2, \mathbf{t}}+\mathbf{\Theta} \mathbf{X}_{\mathbf{c 1}, \mathbf{c} 2, \mathbf{t}}+P A I R_{c l, c 2}+\zeta_{c 1, c 2, t},
$$

where $P A I R_{c l, c 2}$ is the "pair of country" effect and $\zeta_{c l, c 2, t}$ is assumed white. I need to address some econometric issues with this specification. First, to avoid the kind of inconsistent standard errors Bertrand, et al. (2004) warn against, my estimation is done with a bootstrap. Second, the medians could

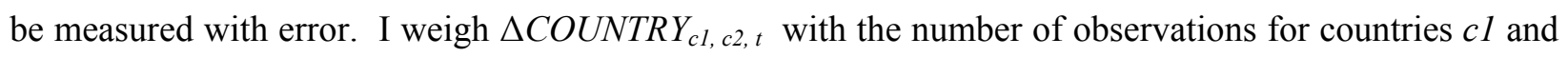
$c 2$ in year $t$. It turns out that the weighing makes no qualitative difference so I report the simpler unweighed results. Third, the innovations $\zeta_{c l, c 2, t}$ are likely to be correlated, not only in the traditional time 
series sense, but also in cross-sections. Consider three countries. Correlation between two pairs of countries can systematically bias correlation of the third pair. I use three methods to deal with this: fixed effects (which could have estimation inefficiency), GLS (generalized least squares, which could have an unrealistic assumption of constant covariance form) and the QAP (quadratic assignment procedure, which is non-parametric; see Fisman and Love (2004), Simpson $\left.(2001)^{5}\right) . \quad$ Each has it weakness, but they all produce qualitatively the same results, so I report just the simpler fixed effects estimation with bootstraps. Finally, the dependant variable is censored from below, so I use Tobit regressions. Since the model is seeking to explain only differences rather than slopes, more characteristics should now appear significant. This is what happens, reported in panel (b). However, the economic significance is still not large. For example, a pair of countries with contract time ratios that is $1 \%$ greater than another pair's ratio has an inventory ratio that is $0.17 \%$ higher. As the results show, only differences in $T R A D E / G D P$ and CONTRACT_TIME - which are proxies for openness and the contracting environment - seem to explain differences in firm-level inventory. In addition, the levels of GDP/CAPITA, TRADE/GDP, and CONTRACT_TIME are significantly and positively correlated with inventory, although the result for GDP/CAPITA has negligible economic significance.

Finally, I should mention that I have considered regional convergence. This possibility is empirically less interesting, because it is consistent with both global contingency (e.g., NAFTA economies converge even as all economics converge) and local contingency (e.g, NAFTA economies convergence because of NAFTA characteristics, and other economies without NAFTA-characteristics do not converge). Therefore, I relegate this analysis to the online appendix. ${ }^{6}$ I find that the number of clusters that maximizes $R$-squared is 10 . Given that there are only 23 countries in the dataset, this suggests that regional convergence is not a major explanation anyway.

\footnotetext{
${ }^{5}$ I am grateful to Bill Simpson for providing me with the code for the QAP procedure.

${ }^{6}$ In this draft for review, the analysis is attached to the back of this document.
} 


\section{CONCLUSION}

I start by asking how different inventory levels are in firms around the world. Specifically, are firmlevel inventories constant across countries, converging, or at least co-integrating? I find evidence to reject these various forms of global determinism. I also report evidence consistent with local contingency, in which country effects can explain inventory differences around the world. I also show that this conclusion is robust in numerous ways.

One of the first qualifications to the above conclusion is that it does not imply that country effects are the best explanation for inventory differences. However, I wish to propose as a "stylized fact" in operations management that global determinism is absent. A natural next step is to study to what extent country, industry, and firm effects contribute to inventory heterogeneity among firms around the world. Theoretically, this means that studies of how country characteristics could affect firm-level inventory policies would be interesting avenues for further research.

Another qualification is that this study is limited to retail firms. Manufacturing firms could have very different inventory management policies. For example, they have significant raw materials and work-inprogress inventories. They are also the target of many just-in-time inventory reduction programs. Another natural path for research is to consider global determinism in manufacturing.

A final note is more speculative. It involves the question of the extent to which new countryspanning technologies such as web-based supply chains could affect the diffusion of inventory levels across firms. Given the recency of these technologies, it is probably hard to persuasively pin down their effects. But the linkage between technology diffusion and operations management would be another fascinating route for future research. 


\section{REFERENCES}

China Statistical Report. Beijing: China Statistical Bureau, 2005

Acemoglu, D., S. Johnson, and J. A. Robinson. "Reversal of Fortune: Geography and Institutions in the Making of the Modern World Income Distribution," The Quarterly Journal of Economics, 117(2002), 1231-1294.

Aghion, P. "Growth and Development: A Schumpeterian Approach," Annals of Economics \& Finance, $5(2004), 1-25$.

Alles, M., A. Amershi, S. Datar, and R. Sarkar. "Information and incentive effects of inventory in JIT production," Management Science, 46(2000), 1528-1544.

Baillie, A. S. "Subcontracting based on integrated standards: the Japanese approach," Journal of Purchasing and Materials Management, 22(1986), 17-21.

Barro, R. J., and X. X. Sala-i-Martin. "Convergence," Journal of Political Econonmy, 100(1992), 223-251.

Bernard, A., and C. I. Jones. "Comparing apples to oranges: Productivity convergence and measurement across industries and countries," American Economic Review, 86(1996), 1216-1238.

Bertrand, M., E. Duflo, and S. Mullainathan. "How Much Should We Trust Differences-in-Differences Estimates?," The Quarterly Journal of Economics, 119(2004), 249-275.

Billesbach, T. J., A. Harrison, and S. Croom-Morgan. "Just-in-time: a United States-United Kingdom comparison," International Journal of Operations \& Production Management, 11(1991), 44-57.

Cachon, G., and M. Olivares. Drivers of Finished Goods Inventory Performance in the U.S. Automobile Industry. Paper presented at the INFORMS 2005, San Francisco, CA, 2005.

Caves, R. E. Industrial Efficiency in Six Nations: Introduction and Summary. Cambridge and London, 1992

Chen, H., M. Frank, and O. Wu. U.S. Retail and Wholesale Inventory Performance from 1981 to 2003. Paper presented at the INFORMS Annual Meeting, San Francisco, 2005a.

Chen, H., M. Z. Frank, and O. Q. Wu. "What Actually Happened to the Inventories of American Companies Between 1981 and 2000?," Management Science, Forthcoming(2005b).

Chikan, A., and D. C. Whybark. "Cross-National Comparison Of Production Inventory ManagementPractices," Engineering Costs and Production Economics, 19(1990), 149-156.

Commerce, U. S. D. o. Manufacturing and Trade Inventories and Sales. Washington, D.C.: U.S. Census Bureau, 2006

Daniel, S. J., and W. D. Reitsperger. "Management control systems for JIT: an empirical comparison of Japan and the US," Journal of International Business Studies, 22(1991), 603-617.

Ferdows, K., M. A. Lewis, and J. A. D. Machuca. Rapid-Fire Fulfillment, Harvard Business Review: 3136,2004

Fischer, S., and O. J. Blanchard. Lectures on Macroeconomics. Cambridge, MA, MIT Press, 1989

Fisman, R., and I. Love. "Financial Development and Intersectoral Allocation: A New Approach," Journal of Finance, 59(2004), 2785-2807.

Friedman, M. "Do Old Fallacies Ever Die?," Journal of Economic Literature, 31(1992), R4.

Gaur, V., M. Fisher, and A. Raman. "An Econometric Analysis of Inventory Turnover Performance in Retail Services," Management Science, 51(2005), 181 ?194.

Ghemawat, P. "Semiglobalization and International Business Strategy," Journal of International Business Studies, 34(2003), 138-152.

Goonatilake, L. "Inventory management in the manufacturing sector in developing countries," Engineering Costs and Production Economics, 19(1990), 19-24.

Guasch, J. L., and J. Kogan. Inventories in Developing Countries: Levels and Determinants - a Red Flag for Competitiveness and Growth. In 2552, W. B. P. R. W. P. N. (Ed.), World Bank Policy Research Working Paper. Washington D.C.: World Bank, 2004

Heckman, J. J. "Sample Selection Bias as a Specification Error," Econometrica, 47(1979), 153-162.

Islam, S. M. N. "What have we learnt from the convergence debate?," Journal of Economic Surveys, 17(2003), 309-362. 
Jorgenson, D. "Productivity and Economic-Growth in Japan and the United-States " American Economic Review, 78(1988), 217-222.

Khanna, T., and J. W. Rivkin. The Structure of Profitability Around the World, Harvard Business School Working Paper 01-056. Boston MA: Harvard Business School, 2001

Khanna, T., J. Kogan, and K. G. Palepu. "Globalization and Similarities in Corporate Governance: A Cross-country Analysis," Review of Economics and Statistics, 88(2006).

Kornai, J. "Resource-constrained versus demand-constrained systems," Econometrica, 47(1979), 801-819.

La Porta, R., F. Lopez-de-Silanes, and A. Shleifer. "Corporate Ownership around the World," Journal of Finance, 54(1999), 471-517.

Lai, R. Inventory Signals, Harvard NOM Working Paper No. 05-15. Boston, MA, 2005

Lieberman, M. B., and L. Demeester. "Inventory reduction and productivity growth: Linkages in the Japanese automotive industry," Management Science, 45(1999), 466-485.

Lieberman, M. B., and R. Dhawan. "Assessing the Resource Base of Japanese and U.S. Auto Producers: A Stochastic Frontier Production Function Approach," Management Science, Forthcoming(2006).

Mao, L. 中國公路Highways in China. Beijing, China, 中華人民共和國交通部, 1996

Matsuura, H., S. Kurosu, and A. Lehtimäki. "Concepts, practices and expectations of MRP, JIT and OPT in Finland and Japan," International Journal of Production Economics, 41(1995), 267-272.

Netessine, S., and S. Roumiantsev. Should inventory policy be lean or responsive: evidence for US public companies. Philadelphia, PA, 2005

North, D. C. Institutions, Institutional Change and Economic Performance. Cambridge, Cambridge University Press, 1990

Ohno, T. Toyota Production System: Practical Approach to Production Management. Cambridge, Cambridge Productivity Press, 1988

Prasad, S., and S. Babbar. "International operations management research," Journal Of Operations Management, 18(2000), 209-247.

Prasad, S., S. Babbar, and J. Motwani. "International operations strategy: current efforts and future directions," International Journal of Operations \& Production Management, 21(2001), 645-665.

Rajagopalan, S., and A. Malhotra. "Have U.S. Manufacturing Inventories Really Decreased? An Empirical Study," Manufacturing and Service Operations Management, 3(2001), 14-24.

Rolland, E., H. Pirkul, and F. Glover. "Tabu search for graph partitioning," Annals of Operations Research, 63(1996), 209-232.

Simpson, W. QAP: The Quadratic Assignment Procedure. Paper presented at the American Stata Users' Group Meeting, 2001.

Sum, C. C., and K. K. Yang. "A study on manufacturing resource planning (MRP II) practices in Singapore," Omega, 21(1993), 187-197.

West, K. D. "A Comparison of the Behavior of Japanese and US Inventories," International Journal of Production Economics, 26(1992), 115-122.

Yi, Y., and M. Gershon. "Implementation of inventory systems in China," International Journal of Operations \& Production Management, 8(1988), 60-66. 


\section{APPENDIX}

Table 1 - Summary Statistics

$$
\text { (a) - Firm-year Observations }
$$

The data is for all retail (NAICS 2000 code 44 through 45) firms from Osiris and COMPUSTAT Global Vantage tapes. Each observation is a firm-year. There are 4,100 unique firms from 23 countries. The period covered is 1983 through 2004. All values are in millions of nominal U.S. dollars, at current exchange rates for non-US firms. Inventory values are scaled by cost of goods sold. Variables are winsorized at $1 \%$ and $99 \%$. Capital intensity is net property, plant, and equipment divided by the sum of net property, plant, and equipment and inventory.

\begin{tabular}{lccc}
\hline & $N$ & Median & Std. dev. \\
\cline { 2 - 4 } Year & 27,508 & $1,999.00$ & 4.66 \\
Inventory - total & 27,508 & 0.15 & 0.25 \\
Inventory - raw materials & 7,899 & 0.005 & 0.09 \\
Inventory - WIP (work in progress) & 6,435 & 0.001 & 0.09 \\
Inventory - finished goods & 10,427 & 0.13 & 0.24 \\
Levered free cash flow margin & 24,261 & 0.04 & 0.43 \\
COGS (cost of goods sold) & 27,508 & 362.17 & $50,864.64$ \\
Market capitalization & 9,522 & 162.82 & $4,082.09$ \\
Assets & 18,815 & 173.36 & $3,488.00$ \\
Gross margin & 27,505 & 0.17 & 0.22 \\
ROE & 25,338 & 0.51 & 666.76 \\
ROA & 25,940 & 0.08 & 0.19 \\
Revenue growth & 21,342 & 0.08 & $5,581.91$ \\
Capital intensity & 18,799 & 0.53 & 0.25 \\
Deferred taxes & 7,530 & 1.15 & 122.76 \\
Common stock & 18,327 & 7.36 & 133.13 \\
Tobin's $q$ & 3,763 & 1.66 & 1.57 \\
Minority share & 6,297 & 0.04 & 317.16 \\
Number of subsidiaries & 18,815 & 2.00 & 45.51 \\
\hline
\end{tabular}

(b) Observations by Country and Year

\begin{tabular}{|c|c|c|c|c|c|c|c|c|c|c|}
\hline & & $N$ & & & $N$ & & & $N$ & & $N$ \\
\hline 1 & Australia & 194 & 7 & Greece & 168 & 13 & Malaysia & 393 & 19 Taiwan & 220 \\
\hline 2 & Canada & 545 & 8 & Hong Kong & 1,000 & 14 & Mexico & 270 & 20 Thailand & 189 \\
\hline 3 & China & 717 & 9 & Indonesia & 184 & 15 & Netherlands & 308 & 21 Turkey & 101 \\
\hline 4 & Denmark & 182 & 10 & Ireland & 153 & 16 & Singapore & 318 & 22 UK & 3,755 \\
\hline 5 & Egypt. & 180 & 11 & Japan & 8,456 & 17 & South Africa & 198 & 23 US & 9,149 \\
\hline 6 & Germany & 114 & 12 & Korea, Rep. & 496 & 18 & Sweden & 218 & & \\
\hline
\end{tabular}

(c) - Firm-years by Listing Status

\begin{tabular}{lcc}
\hline & $N$ & $\%$ \\
\cline { 2 - 3 } Listed & 20,554 & 74.7 \\
Delisted & 3,289 & 12.0 \\
Unlisted & 3,665 & 13.3 \\
\cline { 2 - 3 } Total & 27,508 & 100.0 \\
\hline
\end{tabular}

(d) - Cost Accounting Treatment

\section{Current Cost}

Historic Cost (company does not revalue fixed assets)

Modified Historic Cost (company states assets at cost in its statements but assumes replacement cost for depreciation)

\begin{tabular}{cl}
$N$ & $\%$ \\
\hline 11 & 0.1 \\
8,276 & 79.6 \\
2,107 & 20.3 \\
& \\
\hline 10,394 & 100.0
\end{tabular}


(e) - Distribution by Inventory Accounting Method

\begin{tabular}{lcc}
\hline & $N$. & $\%$ \\
\cline { 2 - 3 } First In, First Out (FIFO) & 2237 & 38.41 \\
Last In, First Out (LIFO) & 806 & 13.84 \\
Specific Identification & 279 & 4.79 \\
Average Cost & 1338 & 22.99 \\
Retail Method (See note below) & 120 & 2.05 \\
Standard Cost & 989 & 16.93 \\
Current or Replacement Cost & 41 & 0.70 \\
No Inventory or information & 14 & 0.24 \\
Total & 5,824 & 100.00 \\
\hline
\end{tabular}

(f) - Country-year Information: Time-Varying

The data is from WDI. To keep this paper of reasonable length, I refer readers to the World Bank's "Country Data Technical Notes" for details of these measures.

http://web.worldbank.org/WBSITE/EXTERNAL/DATASTATISTICS/0,,contentMDK:20461806 menuPK:64133163 pa gePK:64133150 piPK:64133175 theSitePK:239419,00.html

\section{Macroeconomics}

GDP, PPP (constant 2000 international bil \$)

GDP per capita, PPP (constant 2000 international \$)

GDP growth (annual \%)

Inflation, GDP deflator (annual \%)

Real interest rate (\%)

Highest marginal tax rate, corporate rate (\%)

Services, etc., value added (\% of GDP)

\section{Openness}

Trade in goods (\% of GDP)

Foreign direct invest., net inflows (\% of gross capital formation)

Customs and other import duties (\% of tax revenue)

\section{Rule of Law and Governance}

Corruption (\% of mgrs ranking this as major constraint)

Courts ( $\%$ of mgrs not confidence courts uphold property rights)

Courts (\% of mgrs ranking this as a major constraint)

Time to enforce a contract (days)

Procedures to enforce a contract

Management time dealing with officials ( $\%$ of management time)

Policy uncertainty (\% of mgrs ranking this as major constraint)

\section{Technology}

Internet users (per 1,000 people)

Fixed line and mobile phone subscribers (per 1,000 people)

Information and comm.. tech expenditure per capita (US\$)

Computer, comm. and other services (\% of commercial service imports)

\section{Infrastructure}

Air transport, freight (million tons per km)

Container port traffic (mil TEU: 20 foot equivalent units)

Roads, total network (thousand $\mathrm{km}$ )

Roads, paved (\% of total roads)

Roads, goods transported (million ton-km)

Vehicles (per km of road)

Railways, good hauled (bil ton-km)

\begin{tabular}{|c|c|c|c|}
\hline ariable & $N$ & Med & $S D$ \\
\hline$G D P$ & 4856 & 27.6 & 3830 \\
\hline GDPPERCAP & 4856 & 4620.5 & 8203.4 \\
\hline GDPGROWTH & 5279 & 3.53 & 6.30 \\
\hline INFLATION & 4745 & 7.1 & 588.2 \\
\hline INTEREST & 3334 & 6.2 & 20.6 \\
\hline TAX & 658 & 30.0 & 9.5 \\
\hline SERV & 4661 & 51.4 & 13.0 \\
\hline TRADE & 4799 & 51.5 & 52.4 \\
\hline FDI & 4412 & 4.3 & 50.1 \\
\hline CUSTOMS & 970 & 16.2 & 16.9 \\
\hline CORRUPTION & 49 & 31.4 & 19.2 \\
\hline COURTS & 47 & 47.1 & 14.8 \\
\hline COURTSCONSTF & 37 & 15.7 & 10.5 \\
\hline CONTRAC & 160 & 360.0 & 215.3 \\
\hline CONTRACTPROC & 160 & 29.0 & 10.6 \\
\hline MGT_TIME & 47 & 11.0 & 3.8 \\
\hline UNCE $R T A I N T Y$ & 48 & 39.7 & 16.0 \\
\hline INTERNET & 2311 & 3.9 & 102.7 \\
\hline PHONE & 5648 & 62.5 & 278.8 \\
\hline TECHPERC & 276 & 261.0 & 832.8 \\
\hline TECHIMPORTS & 4460 & 25.8 & 15.4 \\
\hline$A I R$ & 4402 & 31.5 & $8,691.8$ \\
\hline PORT & 280 & 2.0 & 41.3 \\
\hline$R O A D S$ & 2108 & 42.2 & $2,564.7$ \\
\hline ROADSPAVED & 1959 & 48.3 & 33.2 \\
\hline RAODSGOODS & 626 & $10,525.5$ & 167,658 \\
\hline VEHICLES & 1337 & 16.0 & 45.9 \\
\hline RAILV & 102 & 3.77 & 303 \\
\hline
\end{tabular}


Table 2 - Strong Global Determinism (Constancy)

$$
\text { (a) - Country Level Test }
$$

All statistics below correspond to $p$-values of .0001 or less.

\begin{tabular}{lc}
\hline & Kruskal-Wallis Chi-Squared Statistics \\
\cline { 2 - 2 } All years, pooled & 4177 \\
2004 cross-section & 352 \\
\hline
\end{tabular}

(b) - Firm Level Test

The figures below are the coefficients of the country effects from the specification:

$$
\begin{gathered}
\text { LOGINVENTORY }_{\text {cift }}=\text { COUNTRY }_{c}+\text { YEAR }_{t}+I N D U S T R Y_{i}+\text { GROSSMARGIN }_{\text {cift }}+ \\
\text { CAPITALINTENSITY }
\end{gathered}
$$

where INVENTORY cift $_{\text {is }}$ the inventory (all, raw materials, work in progress, or finished goods) for firm $f$ in country $c$ in year $t$, scaled by contemporaneous cost of goods sold, COUNTRY $Y_{c}$, INDUSTRY $Y_{i}$, and YEAR the country, industry, and year effects, GROSSMARGIN $N_{\text {citt }}$ is gross profit divided by sales, CAPITALINTENSITY $Y_{\text {cift }}$ is total inventory divided by the sum of total inventory and property, plant, and equipment, and SALESGROWTH $H_{\text {citt }}$ is the year-on-year sales growth, and $\varepsilon_{\text {citt }}$ is assumed to be white. Estimation is done with robust Huber-White standard errors, and clustered

\begin{tabular}{|c|c|c|c|c|c|c|c|}
\hline & COUNTRY $_{C}$ & & COUNTRY & & COUNTRY $_{C}$ & & COUNTRY $_{C}$ \\
\hline 1Australia & -0.24 & 7 Greece & -0.07 & 13 Malaysia & 0.15 & 19 Taiwan & -0.31 \\
\hline 2Canada & 0.02 & 8 Hong Kong & -0.36 & 14 Mexico & 0.08 & 20 Thailand & -0.02 \\
\hline 3China & 0.37 & 9 Indonesia & 0 & 15 Netherlands & -0.28 & 21 Turkey & $-.60^{*}$ \\
\hline 4Denmark & -0.26 & 10 Ireland & -0.02 & 16 Singapore & -0.09 & 22 UK & -0.28 \\
\hline 5Egypt & $.46^{*}$ & 11 Japan & $-.62^{* *}$ & 17 South Africa & $-.47^{*}$ & 23 US & $-.37^{*}$ \\
\hline 6Germany & $-.42^{*}$ & 12 Korea & -0.34 & 18 Sweden & -0.13 & & \\
\hline
\end{tabular}
around industry to minimize serial correlation. ${ }^{* * *}=1 \%$ significance, ${ }^{* *}=5 \%,{ }^{*}=10 \%$.

$N=12121$, adj $R$-squared=.596, $F$ statistic for equality of country effects $=20.39(p$-value $=.000)$ 
Table 3 - Semi-Strong Global Determinism (Convergence)

All estimations are done with robust Huber-White standard errors, and clustered around industry to minimize serial correlation. ${ }^{* * *}=1 \%$ significance, ${ }^{* *}=5 \%,{ }^{*}=10 \%$.

$$
\text { (a) - Country Level Test }
$$

Model (1) is for beta convergence. Its specification is:

$$
\triangle M E D I A N I N V E N T O R Y_{c t}=\text { MEDIANINVENTORY } Y_{c t}+\operatorname{COUNTRY~}_{c}+\varepsilon_{c t}
$$

where MEDIANINVENTORY ${ }_{c t}$ is the median-firm's inventory (scaled by COGS) for country $c$ in year $t, \Delta$ the difference operator, COUNTRY ${ }_{c}$ are country fixed effects, and $\varepsilon_{c t}$ is assumed to be white. Model (2) is for sigma convergence. It uses an $\operatorname{ARIMA}(1)$ specification:

$$
S D\left(M E D I A N I N V E N T O R Y_{t+1}\right)=S D\left(M E D I A N I N V E N T O R Y_{t}\right)+\varepsilon_{t},
$$

\begin{tabular}{|c|c|c|}
\hline & $\begin{array}{c}(1) \\
\text { Beta Convergence }\end{array}$ & $\begin{array}{c}(2) \\
\text { Sigma convergence }\end{array}$ \\
\hline MEDIANINVENTORY & $5.78(1.52)^{* * *}$ & \\
\hline$S D\left(M E D I A N I N V E N T O R Y_{t}\right)$ & & $.03(2.92)$ \\
\hline Intercept & $.02(.25)$ & $.10(.29)$ \\
\hline$N$ & 317 & 21 \\
\hline Adj $R$-sq & .70 & - \\
\hline Regression statistic & $F=14.53$ & Log likelihood=19.14 \\
\hline Regression $p$-value & .0002 & .998 \\
\hline
\end{tabular}

where $S D$ is the standard deviation across countries.

(b) - Firm Level Test

Unlike panel (a) which uses each country's median-firm inventory, this panel uses each country's effects COUNTRY following model, which is run for each year cross-section:

$$
\begin{gathered}
\text { LOGINVENTORY }_{\text {cift }}=\text { COUNTRY }_{c}+I_{N D U S T R Y_{i}}+\text { GROSSMARGIN }_{\text {cift }}+ \\
\text { CAPITALINTENSITY } \\
\text { cift }+ \text { SALESGROWTH } \text { cift }+\varepsilon_{\text {cift }} .
\end{gathered}
$$

\begin{tabular}{|c|c|c|}
\hline & $\begin{array}{c}(1) \\
\text { Beta Convergence }\end{array}$ & $\begin{array}{c}(2) \\
\text { Sigma convergence }\end{array}$ \\
\hline MEDIANINVENTORY & $0.79(.11)^{\star * \star}$ & \\
\hline$S D\left(M E D I A N I N V E N T O R Y_{t}\right)$ & & $.17(7.30)$ \\
\hline Intercept & $.03(.04)$ & $29(2.52)$ \\
\hline$N$ & 98 & 20 \\
\hline Adj $R$-sq & .52 & - \\
\hline Regression statistic & $F=55.43$ & Log likelihood=.19 \\
\hline Regression $p$-value & .000 & .891 \\
\hline
\end{tabular}

For model (1), these country effects are fed into the following:

$\triangle$ COUNTRY $_{c t}=$ COUNTRY $_{c t}+$ COUNTRY $_{c}+\varepsilon_{c t}$,

where $\operatorname{COUNTRY}_{c}$ are country fixed effects. Model (2) uses an ARIMA(1) specification:

$S D\left(\right.$ COUNTRY $\left._{c t+1}\right)=S D\left(\right.$ COUNTRY $\left._{c t}\right)+\varepsilon_{t}$ 
Table 4 - Weak Global Determinism (Co-integration)

All estimations are done with robust Huber-White standard errors, and clustered around industry to minimize serial correlation. ${ }^{* * *}=1 \%$ significance, ${ }^{* *}=5 \%,{ }^{*}=10 \%$.

$$
\text { (a) - Country Level Test (Trends) }
$$

The coefficients of interest are the interaction of COUNTRY (country effects) on YEAR (trend):

$$
\text { MEDIANINVENTORY } Y_{c t}=\text { COUNTRY }_{c}+\text { COUNTRY }_{c} \times Y E A R_{c t}+Y E A R_{c t}+\varepsilon_{c t}
$$

\begin{tabular}{|c|c|c|c|c|c|c|c|}
\hline & COUNTRY $_{C}$ & & COUNTRY & & COUNTRY $_{C}$ & & COUNTRY $_{C}$ \\
\hline 1Australia & -0.006 & 7 Greece & $.018^{\star * *}$ & 13 Malaysia & 0.002 & 19 Taiwan & $\overline{0.004}$ \\
\hline 2Canada & 0.009 & 8 Hong Kong & -0.016 & 14 Mexico & 0.002 & 20 Thailand & 0.011 \\
\hline 3China & -0.006 & 9 Indonesia & -0.001 & 15 Netherlands & 0.004 & 21 Turkey & -0.011 \\
\hline 4Denmark & $.010^{*}$ & 10 Ireland & 0.004 & 16 Singapore & $.027^{\star \star \star}$ & 22 UK & 0.005 \\
\hline 5Egypt & $-.318^{* * *}$ & 11 Japan & 0.007 & 17 South Africa & 0.003 & 23 US & 0.004 \\
\hline 6 Germany & 0.001 & 12 Korea & 0.002 & 18 Sweden & $.012^{*}$ & & \\
\hline
\end{tabular}

where MEDIANINVENTORY $c t$ is the median-firm's inventory (scaled by COGS) for country $c$ in year $t$.

(b) - Country Level Test (Co-integration)

A cointegration test is run for each pair of countries 1 and 2: $C 1$ YEAR $=\mu+\theta . Y E A R_{t}+\beta . C 2$ YEAR $+\eta_{t}$, where $C 1$ YEAR and C2_YEAR are median-firm inventory levels of the countries in year $t$. Then, augmented Dickey-Fuller tests are run on the $192 \eta_{t}$ to see if they are I(0). D-F statistics shown as " 1 " below are those significant at $1 \%$. Percent of cells that have " 1 " $=29.7 \%$.

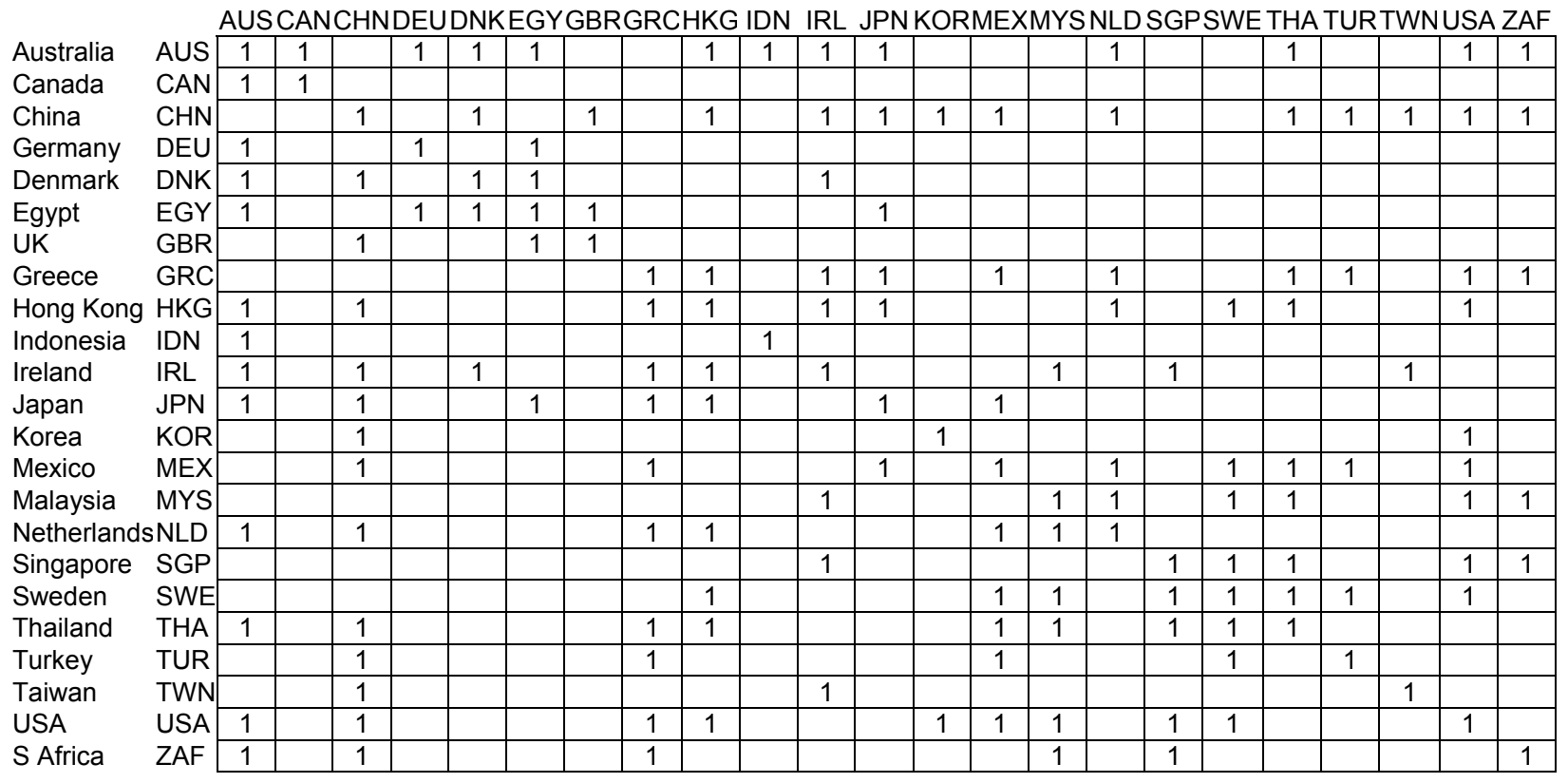




\section{(c) - Firm Level Test (Trends)}

The coefficients of interest are the interaction of $C O U N T R Y_{c}$ (country effects) on YEAR ${ }_{c t}$ (trend):

$L_{\text {LOGINVENTORY }}$ citt $=$ COUNTRY $_{c}+$ COUNTRY $_{c} \times Y_{C A R}$ citt $+Y E A R_{\text {cift }}+I N D U S T R Y_{i}+G R O S S M A R G I N_{\text {cift }}+$

CAPITALINTENSITY $Y_{\text {cift }}+$ SALESGROWTH cift $_{\text {cift }}+\varepsilon_{\text {cift }}$.

where INVENTORY $Y_{\text {citt }}$ is the inventory (all, raw materials, work in progress, or finished goods) for firm $f$ in country $c$ in year $t$, scaled by contemporaneous cost of goods sold, COUNTRY ${ }_{c}$, INDUSTRY ${ }_{i}$, and YEARt the country, industry, and year effects, GROSSMARGIN cift $_{\text {is }}$ gross profit divided by sales, CAPITALINTENSITY by the sum of total inventory and property, plant, and equipment, and SALESGROWTH cift $_{\text {is }}$ the year-on-year sales growth, and $\varepsilon_{\text {cift }}$ is assumed to be white. The estimation is clustered on 6-digit NAICS industry codes.

$N=12121$, adj $R$-squared $=.60, F$ statistic that all trends are equal $=5.17(p$-value $=.000)$

\begin{tabular}{|c|c|c|c|c|c|c|c|}
\hline & COUNTRY $_{C}$ & & COUNTRY $_{C}$ & & COUNTRY $_{C}$ & & COUNTRY $_{C}$ \\
\hline 1 Australia & -0.033 & 7 Greece & $.08^{*}$ & 13 Malaysia & 0.02 & 19 Taiwan & -0.01 \\
\hline 2Canada & 0 & 8 Hong Kong & -0.01 & 14 Mexico & 0.02 & 20 Thailand & $.15^{\star \star *}$ \\
\hline 3China & 0 & 9 Indonesia & 0.04 & 15 Netherlands & 0.02 & 21 Turkey & 0.03 \\
\hline 4Denmark & 0.03 & 10 Ireland & 0 & 16 Singapore & -0.04 & 22 UK & 0 \\
\hline 5Egypt & -0.22 & 11 Japan & 0.02 & 17 South Africa & -0.02 & 23 US & 0.01 \\
\hline 6 Germany & 0.03 & 12 Korea & 0 & 18 Sweden & -0.03 & & \\
\hline
\end{tabular}

(d) - Firm Level Test (Co-integration)

The co-integration statistic for each country pair is obtained as in panel (b), but replacing median-firm inventories with country effects obtained from the following estimated for each year cross-section:

$L_{\text {LOGINVENTORY }}$ ift $=$ COUNTRY $_{c}+$ COUNTRY $_{c} \times Y E A R_{\text {cift }}+Y E A R_{\text {cift }}+I N D U S T R Y_{i}+G_{R O S S M A R G I N}$ cift + CAPITALINTENSITY $Y_{\text {cift }}+$ SALESGROWTH cift $+\varepsilon_{\text {cift }}$.

D-F statistics shown as " 1 " below are those significant at $1 \%$. Percent of cells that have " 1 " $=31.2 \%$.

\begin{tabular}{|c|c|c|c|c|c|c|c|c|c|c|c|c|c|c|c|c|c|c|c|c|c|c|c|c|}
\hline & & AUS & $\Delta N$ & & FI & 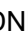 & C & $R$ & R & & DN & $\mathrm{RL}$ & & & A & $4 Y$ & 11 & 0 & WE & $\Gamma \mathrm{H}$ & UF & W & 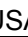 & $A F$ \\
\hline Australia & AUS & 1 & 1 & & 1 & & 1 & 1 & 1 & & & 1 & 1 & & 1 & 1 & 1 & & 1 & 1 & 1 & & & \\
\hline Canada & CAN & 1 & 1 & & 1 & & & 1 & & 1 & & 1 & & & & & 1 & & 1 & 1 & & & 1 & \\
\hline China & $\mathrm{CHN}$ & & & 1 & & & 1 & & & & & & & & & 1 & & & & 1 & & & & \\
\hline Germany & DEU & 1 & 1 & & 1 & & & 1 & & 1 & & 1 & & & & & 1 & & & 1 & & & 1 & \\
\hline Denmark & DNK & & & & & 1 & & & 1 & & & & & & 1 & & & & & & & & & \\
\hline Egypt & EGY & 1 & & 1 & & & 1 & & & & & & & & & & & & & & & & & \\
\hline UK & GBR & 1 & 1 & & 1 & & & 1 & & 1 & & 1 & & & & & & & & 1 & & & & \\
\hline Greece & GRC & 1 & & & & 1 & & & 1 & & & & & & 1 & 1 & & & & & & & & \\
\hline Hong Kong & HKG & & 1 & & 1 & & & 1 & & 1 & & 1 & & & & & 1 & & 1 & 1 & & & 1 & \\
\hline Indonesia & IDN & & & & & & & & & & 1 & 1 & 1 & & 1 & 1 & 1 & & 1 & 1 & 1 & & & \\
\hline Ireland & IRL & 1 & 1 & & 1 & & & 1 & & 1 & 1 & 1 & & & & & 1 & & & & & & 1 & \\
\hline Japan & JPN & 1 & & & & & & & & & 1 & & 1 & & & & & & & & & & & \\
\hline Korea & KOR & & & & & & & & & & & & & 1 & 1 & 1 & 1 & & 1 & 1 & 1 & & & \\
\hline Mexico & MEX & 1 & & & & 1 & & & 1 & & 1 & & & 1 & 1 & & & & & & & & & \\
\hline Malaysia & MYS & 1 & & 1 & & & & & 1 & & 1 & & & 1 & & 1 & & 1 & & & 1 & 1 & & 1 \\
\hline Netherlands & NLD & 1 & 1 & & 1 & & & & & 1 & 1 & 1 & & 1 & & & 1 & & & 1 & & & & \\
\hline Singapore & SGP & & & & & & & & & & & & & & & 1 & & 1 & 1 & 1 & & & 1 & 1 \\
\hline Sweden & SWE & 1 & 1 & & & & & & & 1 & 1 & & & 1 & & & & 1 & 1 & 1 & & & 1 & \\
\hline Thailand & $\mathrm{THA}$ & 1 & 1 & 1 & 1 & & & 1 & & 1 & 1 & & & 1 & & & 1 & 1 & 1 & 1 & & & & \\
\hline Turkey & TUR & 1 & & & & & & & & & 1 & & & 1 & & 1 & & & & & 1 & 1 & 1 & \\
\hline Taiwan & TWN & & & & & & & & & & & & & & & 1 & & & & & 1 & 1 & & \\
\hline USA & USA & & 1 & & 1 & & & & & 1 & & 1 & & & & & & 1 & 1 & & 1 & & 1 & \\
\hline S Africa & ZAF & & & & & & & & & & & & & & & 1 & & 1 & & & & & & 1 \\
\hline
\end{tabular}


Table 5 - Example Robustness Test

(a) - Not Applicable to Sub-samples? (Example: Constancy at Country Level)

All statistics below correspond to $p$-values of .0001 or less.

\begin{tabular}{lc}
\hline & Kruskal-Wallis Chi-Squared Statistics \\
\cline { 2 - 2 } Listed & 3509 \\
Not listed & 707 \\
\hline
\end{tabular}

(b) - Potential Sample Selection Bias? (Example: Constancy at Firm Level)

The selection model for the Heckman sample correction procedure is:

$$
S E L E C T E D_{f t}=Y E A R_{f t}+\text { COMPUSTAT }_{f t}+A_{S S E T S}+\varepsilon_{f t},
$$

where COMPUSTAT $T_{f t}$ is an indicator variable for whether the observation comes from COMPUSTAT, and ASSETS $S_{f t}$ is the total assets of firm $f$ in year $t$. Estimation is done with robust Huber-White standard errors, and clustered around industry to minimize serial correlation. ${ }^{* * *}=1 \%$ significance, ${ }^{* *}=5 \%,{ }^{*}=10 \%$.

$N=21253, \log$ likelihood $=-33655, F$ statistic $=333.89(p$-value $=.000)$

Inverse Mills ratio $=.094$ (standard error $=.052$ )

\begin{tabular}{|c|c|c|c|c|c|c|c|}
\hline & COUNTRY $_{c}$ & & COUNTRY $_{c}$ & & COUNTRY & & $\operatorname{COUNTRY}_{c}$ \\
\hline 1 Australia & $\overline{0.63}$ & 7 Greece & $\overline{0.78}$ & 13 Malaysia & $\overline{0.34}$ & 19 Taiwan & -0.19 \\
\hline 2Canada & 0.11 & 8 Hong Kong & 0.24 & 14 Mexico & 0.61 & 20 Thailand & \\
\hline 3 China & 0.37 & 9 Indonesia & 0.15 & 15 Netherlands & 0.09 & 21 Turkey & -0.46 \\
\hline 4Denmark & 0.54 & 10 Ireland & -0.21 & 16 Singapore & 0.52 & 22 UK & 0.20 \\
\hline 5Egypt & 0.59 & 11 Japan & -0.34 & 17 South Africa & 0.40 & 23 US & 0.42 \\
\hline 6 Germany & 0.43 & 12 Korea & -0.48 & 18 Sweden & 0.04 & & \\
\hline
\end{tabular}

(c) - Country Size Concern (Example: Convergence at Country Level)

This repeats the convergence test using countries smaller than the median area (377,835 sq km): Denmark, Germany, Greece, Hong Kong, Ireland, Korea, Malaysia, Netherlands, Singapore, and United Kingdom. Model (1) is for beta convergence. Its specification is:

$$
\triangle M E D I A N I N V E N T O R Y_{c t}=M_{E D I A N I N V E N T O R Y_{c t}}+\text { COUNTRY }_{c}+\varepsilon_{c t} \text {, }
$$

where MEDIANINVENTORY $c t$ is the median-firm's inventory (scaled by COGS) for country $c$ in year $t, \Delta$ the difference operator, COUNTRY $Y_{c}$ are country fixed effects, and $\varepsilon_{c t}$ is assumed to be white. Model (2) is for sigma convergence. It uses an ARIMA(1) specification:

$$
S D\left(\text { MEDIANINVENTORY } Y_{t+1}\right)=S D\left(\text { MEDIANINVENTORY } Y_{t}\right)+\varepsilon_{t},
$$

where $S D$ is the standard deviation across countries.

\begin{tabular}{lcc}
\hline & $(1)$ & $(2)$ \\
MEDIANINVENTORY & Beta Convergence & Sigma convergence \\
\cline { 2 - 3 } SD(MEDIANINVENTORY & & \\
Intercept & $7.37(0.38)^{* * *}$ & $-.02(20.02)$ \\
$N$ & $-.16(.06)^{* * *}$ & $.09(1.80)$ \\
Adj $R$-sq & 171 & 20 \\
Regression statistic & .92 & - \\
Regression $p$-value & $F=373.2$ & Log likelihood $=14.98$ \\
& .000 & .999 \\
\hline
\end{tabular}


Table 6 - Correlations with Country Characteristics

Estimation is done with robust Huber-White standard errors. ${ }^{* * *}=1 \%$ significance, ${ }^{* *}=5 \%,{ }^{*}=10 \%$.

(a) - Panel Fixed Effects Estimation

Model (1) uses firm and year fixed effects: $L O G I N V E N T O R Y_{f t}=Y E A R_{t}+F_{I R M_{f}}+\mathbf{C}_{\mathrm{ft}}+\varepsilon_{f t}$, where $\mathbf{C}_{\mathrm{ft}}$ are timevarying country characteristics (in table below). Model (2) uses OLS: $L O G I N V E N T O R Y_{\text {cift }}=Y_{E A R}+I N D U S T R Y_{i}+$ $\mathbf{F}_{\text {cift }}+\mathbf{C}_{\text {cift }}+\varepsilon_{\text {cift }}$, where $\mathbf{F}_{\text {cift }}$ are firm characteristics (gross margin, capital intensity, sales growth).

\begin{tabular}{lcc}
\hline & \multicolumn{1}{c}{$(1)$} & $(2)$ \\
& Fixed effects & OLS \\
\cline { 2 - 3 } GDPGROWTH & $.00(.02)$ & $-.01(.03)$ \\
LOGINFLATION & $.04(.06)$ & $-.18(.07)^{\star *}$ \\
LOGINTERESTRATE & $-.01(.08)$ & $.00(.05)$ \\
LOGGDP/CAPITA & $.87(3.83)$ & $-.39(.22)^{\star}$ \\
LOGTRADE/GDP & $.17(.72)$ & $.00(.08)$ \\
LOGCONTRACTTIME & - & $.07(.10)$ \\
LOGPHONE & $-.17(.47)$ & $.08(.19)$ \\
LOGAIR & $-.05(.24)$ & $-.06(.03)^{\star}$ \\
Intercept & $-9.96(35.48)$ & $2.28(1.54)$ \\
$N$ & 1683 & 1683 \\
Adj R-squared & .93 & .53 \\
F statistic on country characteristics & .332 & 11.74 \\
$p$-value & .939 & .000 \\
\hline
\end{tabular}




\section{(b) - Differences-in-Difference}

This uses a bootstrap Tobit differences-in-differences panel estimation. Each observation is a country pair in a year. The dependant variable is the difference metric between country effects of the countries $c 1$ and $c 2$ in year $t$, obtained from year-by-year cross-sectional estimations:

$$
\begin{gathered}
\text { LOGINVENTORY }_{\text {cift }}=\text { COUNTRY }_{c}+\text { INDUSTRY }_{i}+\text { GROSSMARGIN }_{\text {cift }}+ \\
\text { CAPITALINTENSITY } \\
\text { cift }
\end{gathered}
$$

The difference metric is:

$$
\triangle \text { COUNTRY }_{c 1, c 2, t}=\log \left(\max \left(\text { COUNTRY }_{c 1, t}, \text { COUNTRY }_{c 2, t}\right) / \min \left(\text { COUNTRY }_{c 1, t}, \text { COUNTRY }_{c 2, t}\right)\right)
$$

The independent variables include $\Delta \mathbf{X}_{c 1, c 2, t}$, differences in country characteristics - e.g., for GDPGROWTH: $\triangle$ GDPGROWTH $_{c 1, c 2, t}=\log \left(\max \left(G D P G R O W T H_{c 1, t}\right.\right.$ GDPGROWTH $\left.H_{c 2, t}\right) / \min \left(G D P G R O W T H_{c 1, t}\right.$, GDPGROWTH G $\left.\left.2, t\right)\right)$ for countries $c 1$ and $c 2$ in year $t$. Other independent variables include $\Theta \mathbf{X}_{c 1, c 2, t}$, the average levels - e.g.:

$$
\Theta G D P G R O W T H_{c 1, c 2, t}=\left(G D P G R O W T H_{c 1, t}+G D P G R O W T H_{c 2, t}\right) / 2 \text {. }
$$

\begin{tabular}{|c|c|c|}
\hline & & $\triangle$ COUNTRY $_{c 1, c 2, t}$ \\
\hline \multirow[t]{2}{*}{ GDP GROWTH } & Diff & $-.04(.03)$ \\
\hline & Average & $-.02(.02)$ \\
\hline \multirow{2}{*}{ INFLATION } & Diff & $-.07(.04)^{*}$ \\
\hline & Average & $.00(.02)$ \\
\hline \multirow[t]{2}{*}{ INTEREST } & Diff & $.04(.04)$ \\
\hline & Average & $.00(.01)$ \\
\hline \multirow{2}{*}{ GDP/CAPITA } & Diff & $.05(.08)$ \\
\hline & Average & $.00004(.00000)^{* * *}$ \\
\hline \multirow[t]{2}{*}{ TRADE/GDP } & Diff & $.11(.04)^{\star *}$ \\
\hline & Average & $.003(.001)^{* * *}$ \\
\hline \multirow[t]{2}{*}{ CONTRACT_TIME } & Diff & $.17(.05)^{\star * *}$ \\
\hline & Average & $.0015(.0004)^{\star * *}$ \\
\hline \multirow{2}{*}{ PHONE } & Diff & $-.10(.08)$ \\
\hline & Average & $.00(.00)$ \\
\hline \multirow[t]{2}{*}{ AIR } & Diff & $.03(.02)^{*}$ \\
\hline & Average & $.00(.00)$ \\
\hline Intercept & & $1.42(.33)^{* * *}$ \\
\hline$N$ & & 290 \\
\hline Log likelihood & & -95.91 \\
\hline Wald of test on country characteristics & & 132.26 \\
\hline$p$-value & & .000 \\
\hline
\end{tabular}

The model is therefore:

$$
\triangle \text { COUNTRY }_{c 1, c 2, t}=\Delta \mathbf{X}_{\mathrm{c} 1, \mathrm{c} 2, \mathrm{t}}+\Theta \mathbf{X}_{c 1, c 2, t}+P A I R_{c 1, c 2}+\zeta_{c 1, c 2, t},
$$

where $P A I R_{c 1, c 2}$ is the "pair of country" effect, $\zeta_{c 1, c 2, t}$ is assumed white. 
Figure 1 - Median-Firm Inventory by Country - 2004

The vertical axis is total inventory (scaled by COGS) of the median firm in each country, in year 2004. The data is for all retail (NAICS 2000 code 44 through 45) firms from Osiris and COMPUSTAT Global Vantage tapes. Each observation is a firm-year. There are 4,100 unique firms from 23 countries. The period covered is 1983 through 2004. All values are in millions of nominal U.S. dollars, at current exchange rates for non-US firms. Inventory values are scaled by cost of goods sold. Variables are winsorized at $1 \%$ and $99 \%$.

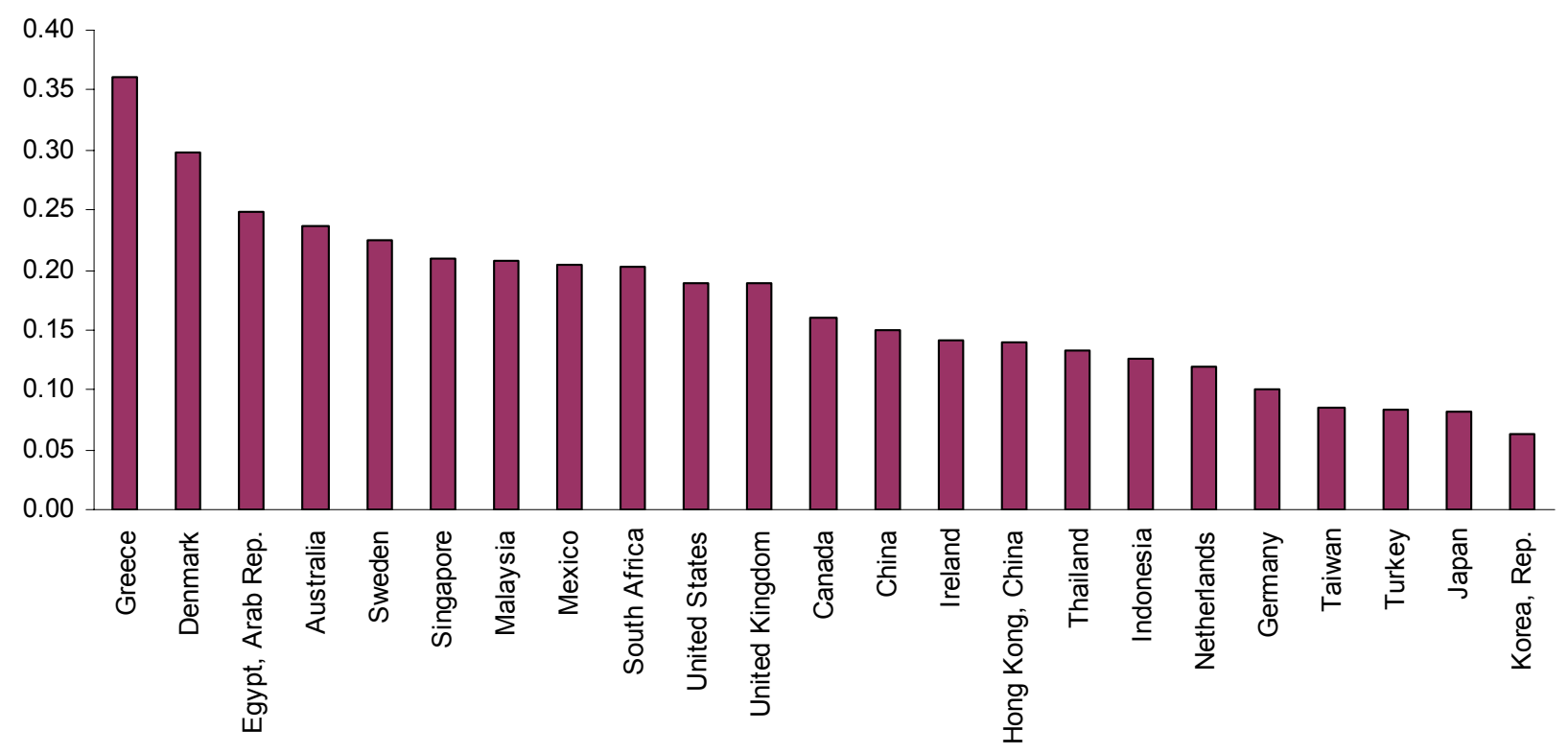

Figure 2 - Median-Firm Inventory and GDP/Capita, Year 2004

The vertical axis is total inventory (scaled by COGS) of the median firm in each country. The horizontal axis is GDP/capita, at PPP constant 2000 international dollars.

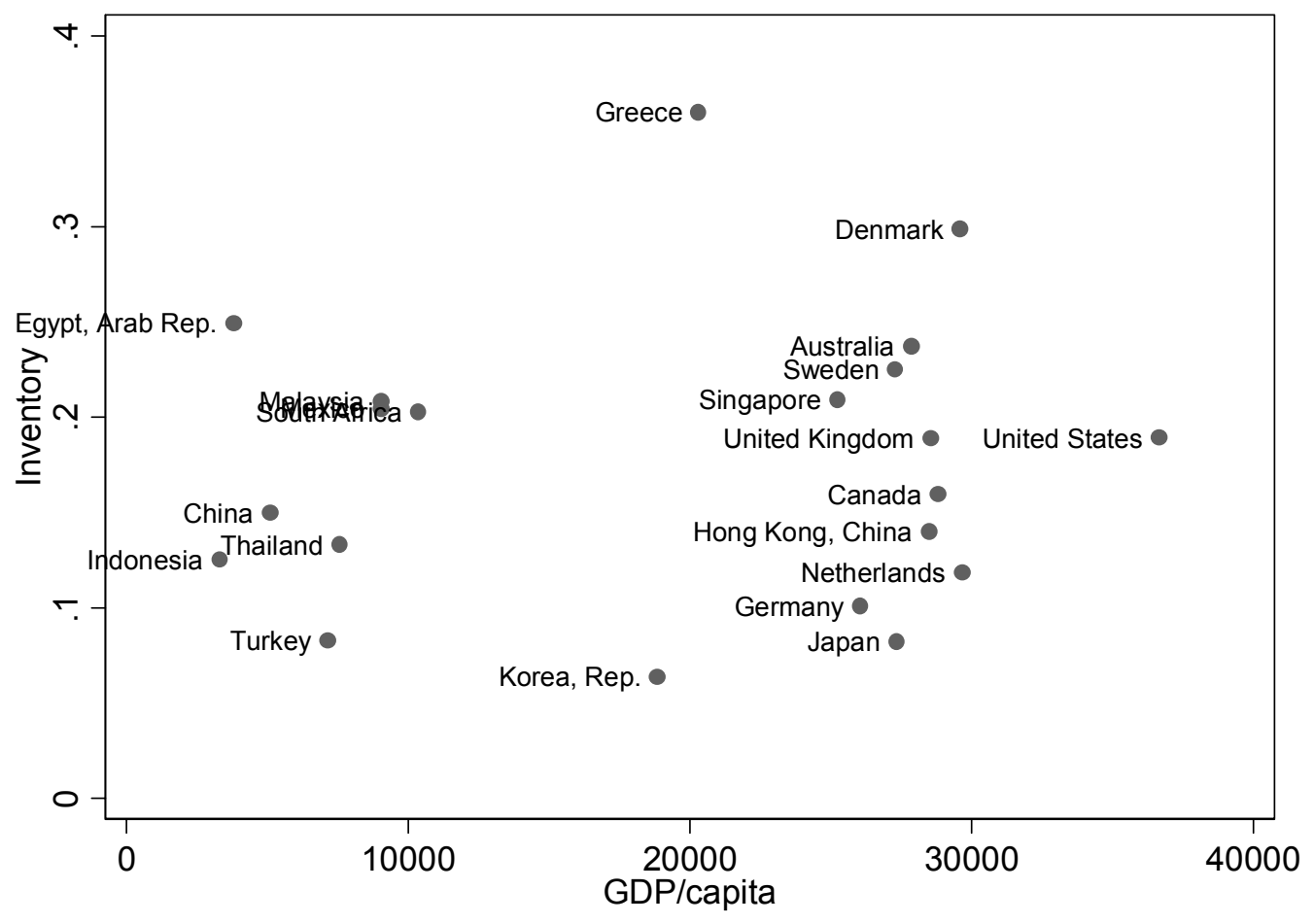




\section{ONLINE APPENDIX}

\section{(ONLY FOR REVIEWERS; NOT TO BE CONSIDERED PART OF DOCUMENT SUBMITTED)}

Table 7 - Regional Convergence

In this example, we report regional convergence for the Co-integration Firm Level Test (in Table 4, panel (d)). I use a cluster analysis algorithm that optimizes a cost function which measures the total distance or similarity within classes for a proximity matrix (see Rolland, et al. (1996)).

The number of clusters that produces the highest explanatory power $(R$-squared $=0.30)$ is 10 . The following illustrates the case for 3 clusters.

\begin{tabular}{|c|c|c|c|c|c|c|c|c|c|c|c|c|c|c|c|c|c|c|c|c|c|c|}
\hline & \multicolumn{20}{|c|}{$\begin{aligned} & R \text {-squared }=-.21 \\
& \text { AUSSW }\end{aligned}$} \\
\hline Austr AUS & 1 & & & & 1 & & 1 & & 1 & & 1 & 1 & 1 & & 1 & & 1 & 1 & 1 & 1 & 1 & \\
\hline Swec SWE & & 1 & & 1 & & 1 & & & 1 & 1 & & 1 & & 1 & 1 & & & & & & & \\
\hline Chinc $\mathrm{CHN}$ & & & 1 & & 1 & & 1 & & 1 & 1 & 1 & 1 & 1 & 1 & 1 & 1 & & 1 & & 1 & & 1 \\
\hline Mala! MYS & & 1 & & 1 & 1 & & & & & & 1 & 1 & 1 & & 1 & & & & & & & \\
\hline Nethi NLD & 1 & & 1 & 1 & 1 & & & 1 & 1 & & & & & 1 & & & & & & & & \\
\hline Singe SGP & & 1 & & & & 1 & & & & & 1 & 1 & 1 & & 1 & & & & & & & \\
\hline Japaı JPN & 1 & & 1 & & & & 1 & 1 & 1 & & & & & 1 & & & & & & & 1 & \\
\hline Gree GRC & & & & & 1 & & 1 & 1 & 1 & 1 & 1 & 1 & 1 & 1 & 1 & & & & & & & \\
\hline Hong HKG & 1 & 1 & 1 & & 1 & & 1 & 1 & 1 & & 1 & 1 & & & 1 & & & & & & & \\
\hline Turke TUR & & 1 & 1 & & & & & 1 & & 1 & & & & 1 & & & & & & & & \\
\hline Irelar IRL & 1 & & 1 & 1 & & 1 & & 1 & 1 & & 1 & & & & & 1 & & & & 1 & & \\
\hline Unite USA & 1 & 1 & 1 & 1 & & 1 & & 1 & 1 & & & 1 & & 1 & & & & 1 & & & & \\
\hline South ZAF & 1 & & 1 & 1 & & 1 & & 1 & & & & & 1 & & & & & & & & & \\
\hline Mexic MEX & & 1 & 1 & & 1 & & 1 & 1 & & 1 & & 1 & & 1 & 1 & & & & & & & \\
\hline Thaili THA & 1 & 1 & 1 & 1 & & 1 & & 1 & 1 & & & & & 1 & 1 & & & & & & & \\
\hline Taiw: TWN & & & 1 & & & & & & & & 1 & & & & & 1 & & & & & & \\
\hline Indor IDN & 1 & & & & & & & & & & & & & & & & 1 & & & & & \\
\hline Kore: KOR & & & 1 & & & & & & & & & 1 & & & & & & 1 & & & & \\
\hline Cana CAN & 1 & & & & & & & & & & & & & & & & & 1 & & & & \\
\hline Germ DEU & 1 & & & & & & & & & & & & & & & & & & 1 & & 1 & \\
\hline Denn DNK & 1 & & 1 & & & & & & & & 1 & & & & & & & & & 1 & 1 & \\
\hline Egyp EGY & 1 & & & & & & 1 & & & & & & & & & & & & 1 & 1 & 1 & 1 \\
\hline Unite GBR & & & 1 & & & & & & & & & & & & & & & & & & 1 & 1 \\
\hline
\end{tabular}

Density Matrix of Clusters

\begin{tabular}{|c|c|c|}
\multicolumn{1}{c}{1} & 2 & 3 \\
\hline 0.52 & 0.10 & 0.12 \\
\hline 0.10 & 0.25 & 0.00 \\
\hline 0.12 & 0.00 & 0.63 \\
\hline
\end{tabular}

